\title{
Gender equality in strategic management of the projects in $R \& D$ organisations in Serbia
}

\author{
Vladimir Obradović \\ Faculty of Organisational Sciences \\ University of Belgrade \\ Belgrade, Serbia \\ obradovicv@fon.bg.ac.rs
}

\author{
Marija Mosurović Ružičić \\ Institute Mihajlo Pupin \\ University of Belgrade \\ Belgrade, Serbia \\ marija.mosurovic@pupin.rs
}

\author{
Marina Dobrota \\ Faculty of Organisational Sciences \\ University of Belgrade \\ Belgrade, Serbia \\ marina.dobrota@fon.bg.ac.rs
}

\begin{abstract}
The interest in gender equality issue within the concept of project management is growing in the literature. Bearing in mind that $R \& D$ activities are mostly project-oriented, this paper aims to contribute to a better understanding of gender equality issues in the context of an integrated approach to strategic management of the projects in $R \& D$ organisations. To comprehensively examine these issues, the research on strategic management in R\&D organisations in Serbia, conducted in 2018, will be introduced and analysed. The results presented here point out the need for introducing professional project management in $R \& D$ organisation in Serbia. Gender dimension should be an integral part of the modern strategic concept of managing R\&D organisation.
\end{abstract}

Keywords - gender equality, research and development, project management.

\section{INTRODUCTION}

In modern organisations, nowadays, the number of women in management positions is increasing, which in practice means more female project managers. Nevertheless, the literature dealing with the study of gender equality concepts in terms of project management is relatively scarce. Although not sufficiently represented in project management academic literature, this increased attention to the gender issue is in line with the increasing interest in project management profession [1]. According to the Frascati manual (2015), research and development (R\&D) activities within the organisation at the operational level are mostly realised through programs and projects, so the strategic management of $R \& D$ projects has become of great importance for $R \& D$ organisations today [2].

The purpose of this paper is to contribute to understanding the gender equality aspect as an integral part of the strategic approach to managing projects in $\mathrm{R} \& \mathrm{D}$ organisations. In this work, some of the results of the empirical research on strategic management in R\&D organisations in Serbia, conducted in 2018, will be presented. The attitudes of employees in $R \& D$ organisations on strategic managing of the projects in the aforementioned organisations in Serbia were examined by gender. The obtained results are of great importance at all levels of R\&D management, from project managers, managers of $R \& D$ organisations, as well as policymakers in terms of improving gender balance and project management in theory and practice in Serbia and beyond.

\section{GENDER BALANCE IN R\&D}

The emergence of gender mainstreaming in science as a strategic concept relates to the nineties of the last century, more specifically to 1993., and reflects the tendency of including gender equity consideration in decision-making processes at all levels: $R \& D$ project level, $R \& D$ organisation level and the highest level of decision-making [3]. Gender mainstreaming in $\mathrm{R} \& \mathrm{D}$ organisation means the strategic approach to gender equality through all stages of the strategic of strategic managementplanning, implementation and evaluation [4].

Whenever the topic of project management is raised, the first association are project-oriented organisations (construction, energy, information technology, etc.) in which the women are minority. Understanding the project concept is useful for understanding the way $R \& D$ performs [2]. There is also recommendation in the latest version of the Frascati Manual to collect data regarding the R\&D labour force by gender. According to UNESCO (2018), women are still minority of the world's researchers. According to data from 2015, the regional averages for the share of female researchers are $28.8 \%$ in terms of the world and $39.5 \%$ for Central and Eastern Europe [5].

The larger inclusion of women in R\&D activities has been recognised as an important issue at the European level. Gender balance is recognised as an important ranking factor in project evaluation of the project proposals within Horizon 2020. Project proposals should enable equal opportunities in project teams at all levels, of both, the team members and project managers. Performing R\&D activities in R\&D organisations in Serbia has been under the process of transformation from the second half from the last century. The improvement of the strategic management of $\mathrm{R} \& \mathrm{D}$ projects in $\mathrm{R} \& \mathrm{D}$ organisations in Serbia should enable effective restructuring of these organisations, but at the same time it should improve utilisation and commercialisation of the results of scientific research. The R\&D activities in the abovementioned organisations are mostly financed by 
the government through $\mathrm{R} \& \mathrm{D}$ projects, and divided into three main areas (Table I): basic research, technological development, and interdisciplinary research. Based on the data provided by The Ministry of Education, Science and Technological Development (MESTD) of the Republic of Serbia [6] presented in Table I, it is obvious that differences in gender representation vary depending on the fields of research - there are slightly more women than men in biology (62\%), Medicine Biotechnological and Agricultural sciences and Chemical sciences (51\%). On the other hand, in other scientific fields, project managers are predominantly men.

TABLE I. PROJECT MANAGERS BY GENDER IN R\&D ORGANISATION IN SERBIA

\begin{tabular}{|c|c|c|}
\hline Basic research & $\operatorname{Men}(\%)$ & $\begin{array}{c}\text { Women } \\
(\%)\end{array}$ \\
\hline Physical sciences & 76 & 24 \\
\hline Chemical sciences & 49 & 51 \\
\hline Biological sciences & 38 & 62 \\
\hline $\begin{array}{l}\text { Mathematics, Computer sciences } \\
\text { and Mechanics }\end{array}$ & 85 & 15 \\
\hline Medicine & 49 & 51 \\
\hline Earth Sciences and Astronomy & 57 & 43 \\
\hline $\begin{array}{l}\text { History and archaeology } \\
\text { ethnology }\end{array}$ & 73 & 27 \\
\hline Languages and literature & 54 & 46 \\
\hline Social sciences & 75 & 25 \\
\hline Sum & 61 & 39 \\
\hline Technological development & $\operatorname{Men}(\%)$ & $\begin{array}{c}\text { Women } \\
(\%)\end{array}$ \\
\hline $\begin{array}{ll}\text { Biotechnological } & \text { and } \\
\text { Agricultural sciences } & \end{array}$ & 49 & 51 \\
\hline $\begin{array}{l}\text { Energetics, Mining and } \\
\text { Energetics efficacy }\end{array}$ & 97 & 3 \\
\hline $\begin{array}{l}\text { Materials and } \quad \text { Chemical } \\
\text { technologies }\end{array}$ & 66 & 34 \\
\hline $\begin{array}{l}\text { Mechanical engineering and } \\
\text { industrial software }\end{array}$ & 93 & 8 \\
\hline $\begin{array}{l}\text { Transport, Urban planning and } \\
\text { Construction }\end{array}$ & 75 & 25 \\
\hline $\begin{array}{l}\text { Electronics, telecommunication } \\
\text { and information technologies }\end{array}$ & 75 & 25 \\
\hline $\begin{array}{l}\text { Planning, protection and use of } \\
\text { water, land and air }\end{array}$ & 78 & 22 \\
\hline Sum & 73 & 27 \\
\hline $\begin{array}{c}\text { Integral and interdisciplinary } \\
\text { research }\end{array}$ & $\operatorname{Men}(\%)$ & $\begin{array}{c}\text { Women } \\
(\%)\end{array}$ \\
\hline Biomedicine & 52 & 48 \\
\hline $\begin{array}{l}\text { Energetics and energetics } \\
\text { efficiency }\end{array}$ & 100 & 0 \\
\hline $\begin{array}{l}\text { Environmental protection and } \\
\text { climate changes }\end{array}$ & 91 & 9 \\
\hline $\begin{array}{l}\text { Information and } \\
\text { telecommunication technologies }\end{array}$ & 100 & 0 \\
\hline $\begin{array}{l}\text { New Materials and Nano- } \\
\text { sciences }\end{array}$ & 89 & 11 \\
\hline Agrofood & 50 & 50 \\
\hline $\begin{array}{l}\text { Improvement decision making at } \\
\text { the state level }\end{array}$ & 63 & 37 \\
\hline Sum & 72 & 28 \\
\hline
\end{tabular}

Source: Authors' calculation, 2018 Source MESTD
Within the previous research in Serbia, R\&D organisations were mainly observed through various descriptive studies, mostly related to consideration of the process of strategic management in terms of the organisational context of specific $R \& D$ research organisation, or as part of a larger system, the part of strategic policy documents at the state level. There were no specific, empirical studies on the strategic management of $R \& D$ projects within scientific and research organisations. In particular, the gender aspect of strategic management is not sufficiently explored on $R \& D$ project and $R \& D$ organisation level.

\section{RESEARCH METHODOLOGY}

The conducted research involved employees from the R\&D organisations in Serbia - research institutes and faculties, which were accredited by the competent ministry - The Ministry of Education, Science and Technological Development. The starting point was the basic postulate of strategic management: that it should be understandable to all employees in the organisation, so this questionnaire was distributed to employees in R\&D organisations, institutes and faculties.

To gain insight into the structure of the sample by gender, descriptive statistics were used in this paper and then for determination of statistically significant differences by gender in terms of individual sample characteristics, the Chi-square test was used. The great challenge was to determine variables that describe strategic management process in scientific research organisations. After detailed theoretical analysis, taking into account the specificity of the scientific research system of Serbia, appropriate indicators that describe the process of strategic management in this type of organisation were selected and presented with 13 consistent variables: external environment, internal environment, strategic documents, project portfolio, resources, organisational design, collaboration, monitoring, results, achievement assessment, system of lessons learnt, efficacy assessment, strategic management methods and techniques. The mean value was used for ranking the above-mentioned components of strategic management by importance, by gender.

\section{SAMPLE STRUCTURE BY GENDER}

Respondents estimated that most of their R\&D activities were carried out through projects funded by the competent ministry- MESD.

TABLE II. SOURCES OF FUNDING OF PROJECTS IN R\&D ORGANISATION IN SERBIA

\begin{tabular}{|l|c|}
\hline \multicolumn{1}{|c|}{ Type of funding $\boldsymbol{R \& D}$ projects } & Mean \\
\hline MESTD & 4.31 \\
\hline European Union & 2.29 \\
\hline Public sector & 2.07 \\
\hline Economy & 2.19 \\
\hline Other national financial sources & 1.87 \\
\hline Other international financial sources & 2.08 \\
\hline
\end{tabular}

Source: Authors' calculation, 
Projects funded by the European Union were ranked second. It is rather encouraging that the projects funded by the economy were ranked third (Table II). R\&D activities that are driven by market needs assume one modern $R \& D$ organisation that could translate $R \& D$ activities in economic value. It is in line with one comprehensive approach to strategic management of the $R \& D$ projects which incorporate gender equality dimension.

TABLE III. STRUCTURE SAMPLE BY PROJECT POSITION AND AGE BY GENDER

\begin{tabular}{|l|c|c|}
\hline \multicolumn{1}{|c|}{ Sum (\%) } & Women & Men \\
\hline Total & 56 & 44 \\
\hline Project manager & 48 & 52 \\
\hline Team member & 57 & 43 \\
\hline Project manager (\%) & Women & Men \\
\hline to 35 & - & - \\
\hline $35-55$ & 41 & 59 \\
\hline over 55 & 60 & 40 \\
\hline Team member (\%) & Women & Men \\
\hline to 35 Source: Authors' calculation, & 45 \\
\hline $35-55$ & 56 & 44 \\
\hline over 55 & 62 & 38 \\
\hline
\end{tabular}

In the sample (Table III), there are slightly more women $(56 \%)$, than men (44\%). Table III also shows the structure of the sample by position on the project by gender. More than half of the project managers are men (52\%), while women are in the majority of team members $(57 \%)$.

The sample structure in terms of age is also interesting for further analysis. There are no respondents on the position of the project manager within the age group up to 35 years old. The elders express resistance to abandoning the management of projects in favour of younger colleagues even when they meet the project call requirements for project managing. The problem was recognised at the policy decision-making level, so in the call for the current project cycle, which was announced in 2011 in the general criteria, there was a recommendation that subproject managers should not be older than 40 years. However, in practice, this has not been sufficiently achieved.

\section{STRATEGIC MANAGING OF R\&D PROJECTS IN SERBIA BY GENDER}

The data presented in Table IV illustrate the respondents' attitudes by gender on the importance of implementing strategic management of R\&D projects in $R \& D$ organisations in Serbia. Respondents agree that R\&D organisations should have a strategic approach in managing their projects (men 95\%; women $92 \%$ ). At the moment of survey conducting, less than half of the respondents, regardless of the gender, consider that $\mathrm{R} \& \mathrm{D}$ projects in their organisations were not managed strategically (men $39 \%$, women $44 \%$ ). But there is no statistically significant gender difference regarding this opinion. Men in more statistically significant number $(\mathrm{p}=0.017)$ express their attitude regarding the existence of a specific organisational unit for strategic project management at the organisation level. This could be interpreted by the fact that, since they are in larger number at project management position, based on empirical experience they can more clearly identify the real situation and problems that occur in the managing of $R \& D$ projects at the organisation level.

TABLE IV. STRATEGIC MANAGING OF R\&D PROJECTS BY GENDER IN R\&D

\begin{tabular}{|c|c|c|c|c|}
\hline \multirow{2}{*}{\multicolumn{2}{|c|}{$\begin{array}{l}\text { Strategic managing of } \\
\text { R\&D projects }\end{array}$}} & \multicolumn{2}{|c|}{ Gender (\%) } & \multirow{4}{*}{$\begin{array}{c}\begin{array}{c}\text { Chi- } \\
\text { square }\end{array} \\
0.531\end{array}$} \\
\hline & & Men & Women & \\
\hline \multirow{2}{*}{$\begin{array}{lr}\text { Your } & \text { R\&D } \\
\text { organisation should } \\
\text { have a strategic } \\
\text { approach } & \text { in } \\
\text { managing } & \text { their } \\
\text { projects } & \end{array}$} & Yes & 93 & 92 & \\
\hline & No & 7 & 8 & \\
\hline \multirow{3}{*}{$\begin{array}{lr}\text { There is a special } \\
\text { organisation unit } \\
\text { for } \quad \text { strategic } \\
\text { managing } & \text { R\&D } \\
\text { projects } & \end{array}$} & Yes & 19 & 9 & \multirow[b]{3}{*}{$0.017 *$} \\
\hline & No & 73 & 71 & \\
\hline & $\begin{array}{c}\text { I } \\
\text { don't } \\
\text { know }\end{array}$ & 8 & 20 & \\
\hline \multirow{2}{*}{$\begin{array}{l}\text { Your organisation } \\
\text { manage R\&D } \\
\text { projects on a } \\
\text { strategic way }\end{array}$} & Yes & 39 & 44 & \multirow[b]{2}{*}{0.231} \\
\hline & No & 61 & 56 & \\
\hline
\end{tabular}

Source: Authors' calculation, * $\mathrm{p}<0.05$

Within the survey placed, the three phases of the strategic management process (planning, implementation, and evaluation) in R\&D organisations are described in detail with 13 consistent variables: external environment, internal environment, strategic documents, project portfolio, resources, organisational design, collaboration, monitoring, results, achievement assessment, system of lessons learnt, efficacy assessment, strategic management methods and techniques (Table V).

The project managers from Serbian R\&D organisations have ranked the abovementioned components of strategic management by importance, by gender. According to means values in Table $\mathrm{V}$, it becomes obvious that there are different project management styles in R\&D organisations in Serbia between men and women. Nevertheless, when it comes to ranking of significance of some components of strategic management by project managers by gender, the situation is quite uniform. Firstly, the efficacy assessment is ranked; then, the external environment, while the third-ranked component is the results.

Interestingly, the components poorly ranked by both, women and men (the system of lessons learned ranking 12 and achievement assessment ranked six by men and ranked seven by women) and the most significant ranking component - efficacy assessment 
(ranking 1 in both observed samples) describes the evaluation phase of strategic management.

TABLE V. STRATEGIC MANAGING OF R\&D PROJECTS BY GENDER IN R\&D

\begin{tabular}{|l|c|c|}
\hline \multirow{2}{*}{ Strategic management variables } & \multicolumn{2}{|c|}{ Mean } \\
\cline { 2 - 3 } External environment & 31.69 & 26.31 \\
\hline Internal environment & 15.46 & 15.62 \\
\hline Strategic documents & 12.86 & 10.54 \\
\hline Project portfolio & 21.93 & 18.85 \\
\hline Resources & 15.93 & 12.85 \\
\hline Organisational design & 21.71 & 20.00 \\
\hline Collaboration & 15.71 & 14.92 \\
\hline Monitoring & 13.79 & 8.92 \\
\hline Results & 24.57 & 22.38 \\
\hline Achievement assessment & 18.79 & 15.46 \\
\hline System of lessons learnt & 12.71 & 7.77 \\
\hline Efficacy assessment & 48.64 & 44.85 \\
\hline $\begin{array}{l}\text { Strategic management methods } \\
\text { and techniques }\end{array}$ & 6.79 & 5.92 \\
\hline
\end{tabular}

Source: Authors' calculation,

The respondents estimated that for the evaluation phase, the quantitative evaluation of the project results is of the greatest importance. The system of lessons learned and the achievement assessment, on the other hand, were not estimated as important enough for strategic management of R\&D organisations in Serbia. The system of lessons learned enables organisation to select, based on past and current project activities, relevant information important for future project activities. This is the process of forming the base of lessons learned from realised or ongoing projects. The system of lessons learned is a typical way of collecting and retaining knowledge from the projects.

Beside the conclusions based on the data from Table V, it is noticeable that the greatest difference in ranking the importance of the components of strategic management by gender can be observed regarding the strategic management components: the resources (ranked 9 by men and ranked 7 by women) and the internal environment (ranked 9 by men and ranked 6 by women). This may indicate that women on project manager's positions express wider analytical understanding regarding internal resources of the organisation, for they were the ones that ranked the internal environment as the $6^{\text {th }}$ most important factor in the strategic management of R\&D organisation, while men ranked it as the $9^{\text {th }}$. The analysis of the internal environment represents the capacity of the organisation to carry out $\mathrm{R} \& \mathrm{D}$ activities and has an undoubtedly significant place within the framework of the strategic management model. At the internal level, $\mathrm{R} \& \mathrm{D}$ are guided by the views of management, marketing, information technologies, elements of organisational design, knowledgebase, internal resources, etc. [7][8].

\section{CONCLUSION}

Gender mainstreaming should be an important part of the strategic management concept in $R \& D$ organisations on both - the level of the entire organisation, and at the level of $R \& D$ projects. The establishing of gender balance at the level of $R \& D$ projects will enable the implementation of long-term strategies to achieve gender equity. The results presented in this paper show that women are insufficiently engaged as project managers in $R \& D$ organisations in Serbia. The main recommendation is to encourage their participation in project management positions within future project calls. Yet another reason is the absence of significant difference regarding the ranking of individual components of strategic management. Both men and women have the same assumptions to become successful project managers, and the same chances should be enabled through gender mainstreaming. The presented research has shown that project managers in $R \& D$ organisations, regardless of gender, understand the evaluation phase only as assessment of quantitative project outcomes. Insufficient knowledge of the evaluation phase indicates the need for introducing professional project management to R\&D organisations. The professional project management should become crucial for the modern strategic concept of managing $\mathrm{R} \& \mathrm{D}$ organisation, in which gender dimension should be an integral part.

\section{ACKNOWLEDGEMENT}

The paper is a result of research within Projects: No. 179081- Researching contemporary tendencies of strategic management- using specialized management disciplines in function of competitiveness of Serbian economy and No. 47005- Research and Development of platform for scientific decision support as well as management for scientific and technological development in Serbia, financed by the Ministry of Education, Science and Technological Development of the Republic of Serbia.

\section{REFERENCES}

[1] L. Henderson and R.W. Stackman, "An Exploratory Study of Gender in Project Management: Interrelationships With Role, Location, Technology, and Project Cost," Project Management Journal, vol. 5, December 2010, pp. 37-55.

[2] OECD, Frascati Manual 2015: Guidelines for Collecting and Reporting Data on Research and Experimental Development, The Measurement of Scientific, Technological and Innovation Activities, OECD Publishing, Paris. DOI: http://dx.doi.org/10.1787/9789264239012-en

[3] UNESCO, Guidelines for gender mainstreaming in science and technology, RESGEST, Jakarta, 2004

[4] M. Mosurović Ružičić and V. Obradovic, "Gender Equality in R\&D," in R\&D Magazine- R\&D Management section, vol. 61, February 2019, pp. 30-35.

[5] UNESCO, Women in Science, Fact Sheet No.51, June 2018.

[6] Ministry of Education, Science and Technological Development of the Republic of Serbia, http://www.mpn.gov.rs/ 
[7] Z. T. Lau, "Title of paper with only first word capitalized," Making Sense of Contemporary Strategic Implementation: Towards A Conceptual Model", Public Administration \& Management: An Interactive Journal, vol. 4, 1999, pp. 494507.

[8] A. Hidalgo and J. Albors, "Innovation management techniques and tools: a review from theory and practice", vol. 38, 2008, pp. 113-127. 